Diabetologia 8, $391-397$ (1972)

(C) by Springer-Verlag 1972

\title{
Induction of Diabetic Alterations by Goldthioglucose-0besity in KK, ICR and C57BL Mice
}

\author{
T. Matsuo and A. Shino \\ Biological Research Laboratories, Central Research Division, Takeda Chemical Industries, Ltd., Osaka, Japan
}

Received: July 24, 1972, accepted: August 24, 1972

Summary. The effect of gold thioglucose (GTG) obesity on development of diabetes was investigated in genetically diabetic (KK) and normal (ICR and C57BL) mice. GTG obesity intensified diabetic traits in KK mice from chemical diabetes to overt diabetes, as was already demonstrated in obesity induced by either dietary or genetical means. GTG obesity caused diabetic changes likewise in ICR mice as manifested by hyperglycemia, glucosuria, hyperinsulinemia, and depressed insulin sensitivity. In vitro glucose oxidation was also decreased to about half of the untreated controls and became less sensitive to added insulin in the epididymal adipose tissue from GTG-obese ICR mice. Hypertrophy of pancreatic islets associated with degranulation of $B$ cells was also recognized in the obese mice. By contrast, either hyperglycemia or glucosuria did not develop in GTG-obese C57BL mice, although the other diabetic changes observed in GTG-obese ICR mice were induced but only in lesser extents. These results indicate that mice inherit their own diabetic potentials and add further experimental evidence for the concept that obesity accelerates the development of diabetes.

Induction d'altérations diabétiques par l'obésité due a l'aurothioglucose chez des souris $K K, I C R$ et $C 57 B L$

Résumé. L'effet de l'obésité due à l'aurothioglucose (GTG) sur le développement du diabète a été étudié chez des souris génétiquement diabétiques (KK) et chez des souris normales (ICR et C57BL). L'obésité due à l'aurothioglucose accentuait les symptômes diabétiques chez les souris KK et transformait leur diabète chimique en diabète manifeste, comme cela a été déjà démontré dans l'obésité provoquée soit par le régime, soit par des moyens génétiques. L'obésité due à l'aurothioglucose provoquait également chez les souris ICR des altérations diabétiques qui se manifestaient par l'hyperglycémie, la glycosurie, l'hyperinsulinémie et une sensibilité diminuée envers l'insuline. L'oxydation du glucose in vitro était également diminuée de moitié environ par rapport aux animaux non traités, et était moins sensible à l'addition d'insuline dans le tissu adipeux épididymaire de souris ICR rendues obèses par l'aurothioglucose. Une hypertrophie des îlots pancréatiques associée à une dégranulation des cellules bêta a été également constatée chez les souris obèses. Par contre, on n'a pas constaté d'hyperglycémie ni de glycosurie chez les souris C57BL obèses par l'aurothioglucose, bien que les autres altérations diabétiques observées chez les souris ICR obèses par l'aurothioglucose aient été provoquées, mais seulement à un moindre degré. Ces résultats indiquent que les souris héritent de leur propre potentiel diabétique, et apportent des preuves expérimentales supplémentaires à l'idée que l'obésité accélère le développement du diabète.

Entwicklung von diabetischen Veränderungen im Verlaufe der Goldthioglucose-Fettsucht bei $K K$, ICR und C57BL Mäusen

Zusammenfassung. Die Einwirkung der durch Goldthioglucose induzierten Fettsucht auf die Entwicklung des Diabetes wurde bei hereditär diabotischen (KK) und normalen (ICR und C57BL) Mäusen untersucht. Die Fettsucht, welche durch eine Goldthioglucoseinjektion erzielt wurde, verschlimmerte die diabetische Stoffwechsellage bei den KK-Mäusen vom latenten Diabetes zum „manifesten" Diabetes, wie dies schon bei der durch diätetische oder genetische Veränderungen erzeugten Fettsucht gezeigt wurde. ICR Mäuse mit Fettsucht durch Goldthioglucose entwickelten die typischen Symptome von Diabetes mellitus, wie Hyperglykämie, Glucosurie, Hyperinsulinämie, Degranulation der B-Zellen in den Inseln des Pancreas eine geringere Empfindlichkeit gegenüber Insulin bei der Glucoseoxidation des Fettgewebe in vitro. Eine Fettsucht wurde auch bei den C57BL Mäusen nach Goldthioglucose Injektion entwickelt, aber weder Hyperglykämie noch Glucosurie wurden erzeugt, trotzdem entwickelten sich eine schlechte Glucosetoleranz, und eine Hyperinsulinämie mit geringgradigeren histologischen sowie biochemischen Veränderungen als bei den KK und ICR Mäusen. Die vorliegenden Resultate, die bei den drei Mäusestämmen mit verschiedenen genetischen Anlagen zum Diabetes beobachtet wurden, unterstützen das Konzept, daß die Fettsucht die Entwicklung von diabetischen Symptomen beschleunigt.

Key words: Goldthioglucose obesity, Hyperglycemia, Hyperinsulinemia, Pancreatic islet, KK mice, Strain difference, Resistance to insulin, Epididymal adipose tis. sue, Glucose oxidation, Lipogenesis.

\section{Introduction}

Our previous papers $[1,2]$ have indicated that KK mice inherit a character for chemical diabetes which develops into overt diabetes following the development of obesity, induced nutritionally by feeding a high caloric diet, or genetically by introduction of the yellow obese $\mathrm{A}^{\mathrm{y}}$ gene. In contrast, ICR mice did not develop any diabetic signs as a result of moderate obesity following the same diet. Our experiments using KK,
C57BL and their hybrids with or without the yellow obese gene further suggested that congenital resistance was determined by several genes inherited in KK mice and the inherited genes were primarily involved in the diabetic traits that were exaggerated by development of obesity [3].

These results emphasized the importance of two diabetogenic factors; one is a predisposition to diabetes genetically inherent in each strain (of mice) and the other is potentiation of this by obesity (either nutritio- 
nal or genetic), both factors are unfluenced by a third factor of aging. As judged from the tolerance tests with glucose and insulin, genetic potentiality of the diabetic trait was highest in KK mice, much lower in ICR mice and lowest in C57BL mice. Hypothalamic lesion with goldthioglucose (GTG) is known to induce remarkable obesity due to hyperphagia. In order to obtain further knowledge on the interplay of these two factors, the present studies have been undertaken to examine the effect of GTG-induced obesity on the development of diabetes in three strains of mice with different diabetic potential. tent was analyzed by the combined methods of Gerson [9] and Abell et al. [10] after saponification. Triglycerides were also eluted with chloroform and determined by the method of Van Handel and Zilversmit [11]. Phospholipids were eluted with methanol and analyzed for phosphorus as described by King [12].

In vitro studies on glucose oxidation and lipogenesis: Epididymal fat pads weighing about $100 \mathrm{mg}$ were placed into a $15 \mathrm{ml}$ flask equipped with a central well. The flask contained $1 \mathrm{ml}$ of Krebs-Ringer bicarbonate buffer $\mathrm{pH}$ 7.4 , containing $20 \mu \mathrm{mol}$ of glucose $(0.01 \mu \mathrm{Ci}$ of glucose- 1 $\left.{ }^{14} \mathrm{C}\right)$ and $2 \mathrm{mg}$ of gelatin with or without insulin $(0.1$ or $1 \mathrm{mU} / \mathrm{ml})$. The flasks were gassed with $95 \% \mathrm{O}_{2}-5 \%$ $\mathrm{CO}_{2}$ mixture, capped with rubber stoppers and then incubated for 90 min at $37^{\circ} \mathrm{C}$ with continuous shaking.

Table 1. Effect of GTG treatment on body weight, blood glucose, glucosuria and food intake in $K K$ mice

\begin{tabular}{|c|c|c|c|c|c|c|c|}
\hline Strai & Group & $\begin{array}{l}\text { No. of } \\
\text { mice }\end{array}$ & $\begin{array}{l}\text { Tnitial } \\
\text { body wt. } \\
\text { g }\end{array}$ & $\begin{array}{l}\text { Final } \\
\text { body wt. } \\
\text { g }\end{array}$ & $\begin{array}{l}\text { Blood } \\
\text { glucose } \\
\mathrm{mg} / 100 \mathrm{ml}\end{array}$ & $\begin{array}{l}\text { Gluco- } \\
\text { suria }\end{array}$ & $\begin{array}{l}\text { Food } \\
\text { intake } \\
\text { g/day }\end{array}$ \\
\hline $\mathrm{KK}$ & $\begin{array}{l}\text { GTG-obes } \\
\text { Control }\end{array}$ & $\begin{array}{l}11 \\
10\end{array}$ & $\begin{array}{l}25 \pm 0.3^{a} \\
26 \pm 0.3\end{array}$ & $\begin{array}{l}36 \pm 0.2^{\mathrm{b}} \\
31 \pm 0.8\end{array}$ & $\begin{array}{l}308 \pm 14^{b} \\
145 \pm 7\end{array}$ & $\begin{array}{c}11 / 11^{\mathbf{c}} \\
0 / 10\end{array}$ & $\begin{array}{l}5.5 \pm 0.1^{b} \\
4.4 \pm 0.1\end{array}$ \\
\hline
\end{tabular}

The mice were kept on powdered $\mathrm{CE} 2 \operatorname{diet}$ for 6 weeks after the intraperitoneal injection of GTG.

a $M \pm S . E$.

b Significant $(p>0.001)$ compared with control.

c Number of mice showing glucosuria/number of mice tested.

\section{Experimental Methods}

Treatment of animals: Specific pathogen-free, male mice of KK, ICR and C57BL strains were used in these studies. KK mice, derived from the original stock [4] and C57BL mice, introduced from National Institute of Genetics, Japan, arose from the inbred colony maintained in our laboratory. ICR mice were purchased from CLEA Japan, Inc. The animals were weaned at the age of 3 weeks and fed on a stock diet, No. CE 2 (Clea Japan, Inc.) ad libitum throughout the experimental periods. The diet contains $56 \%$ nitrogen-free extract, $24 \%$ protein and $3.5 \%$ fat.

Crystalline goldthioglucose (GTG) (Shering Co.), suspended in seasame oil, was injected intraperitoneally at 4 to 6 weeks of age. The dose was approximate to the $\mathrm{LD}_{50}$ for each strain of mice, namely, 0.9 or $1.2 \mathrm{mg} / \mathrm{g}$ body weight for $\mathrm{KK}$ mice, $0.7 \mathrm{mg} / \mathrm{g}$ for ICR mice and $1.0 \mathrm{mg} / \mathrm{g}$ for C57BL mice. After the administration of GTG, the surviving mice were placed in individual metal cages at a room temperature of $24+1^{\circ} \mathrm{C}$ for 6 to 26 weeks. Of the GTG-treated mice, the animals which showed obesity throughout the feeding period were used as GTG-obese mice for the present studies. In experiment shown in Table 1, the mice were fed on the powdered chow CE 2 in order to facilitate daily measurement of food intake.

Chemical procedures: Blood samples were obtained from the orbital vein plexus with capillary glass. Blood glucose was measured by the glucose oxidase method [5].

Plasma insulin was estimated as immunoreactive insulin (IR) [6] by using an immunoassay Kit (Radiochemical Center, Amersham, England).

Liver lipids were extracted by Folch's method [7] and were then separated into major lipid classes by means of thin layer chromatography [8] with a solvent mixture of petroleum ether, diethyl ether and glacial acetic acid $(84: 15: 1, v / v)$. Cholesterol esters and cholesterol were eluted with chloroform from silica gel powder. Both cholesterol fractions were combined and the cholesterol con-
At the end of incubation, $0.4 \mathrm{ml}$ of Hyamine solution (Packard Instrument Co.) was injected into central well through the rubber stopper. Thereafter, $0.5 \mathrm{ml}$ of $1 \mathrm{~N}$ $\mathrm{H}_{2} \mathrm{SO}_{4}$ was added to the incubation mixture. Evolved ${ }_{14} \mathrm{CO}_{2}$ was trapped in the Hyamine solution which was subjected to scintillation counting for radioactivity [2].

For determination of lipogenesis, epididymal fat pads or liver slices were incubated in the same manner as described above, with the following modification; to the incubation mixture, 4 umol of sodium acetate- $1{ }^{14} \mathrm{C}(1 \mu \mathrm{Ci})$ and $20 \mu \mathrm{mol}$ of non-radioactive glucose were added in place of labeled glucose. After the incubation, tissues were transferred into $3 \mathrm{ml}$ of alcoholic $\mathrm{KOH}$ and saponified for $3 \mathrm{~h}$. Fatty acids wore extracted with petroleum ether in the usual way and then subjected to measurement of radioactivity. The details of the experimental procedures were fully described in our previous papers $[2,13]$.

Histological procedures: The aldehyde fuchsin technique [14] was used to stain B granules in the islets of pancreas fixed in Bouin's solution.

\section{Results}

$K K$ mice: KK mice receiving GTG showed a marked increase in body weight, which could be accounted for by elevated food intake (Table 1). These obese KK mice were glucosuric and hyperglycemic. Histological observation revealed hypertrophy of pancreatic islet and degranulation of $B$ cell from these mice. On the other hand, control KK mice did not show any change clinically or pathologically.

This evidence indicated that obesity secondary to hyperphagia induced the same diabetic changes that were seen in genetically obese $\mathrm{KK}$ (yellow $\mathrm{KK}$ ) [2] or 
nutritionally obese $\mathrm{KK}$ mice, fed on high caloric diet [1].

C57BL mice: GTG administration resulted in development of obesity in C57BL mice, demonstrated by marked increases in body weight and adipose tissue weight (Table 2). There was observed an elevation of the plasma insulin level (Table 2), concomitant with hypertrophy of pancreatic islets and degranulation of $B$ cell. In spite of these changes, neither glucosuria nor hyperglycemia developed in these obese mice (Table 2). In (acetate/glucose ratio) would possibly exclude misinterpretation of adipose tissue metabolism due to changes in cellularity resulting from hypertrophy. The acetate/ glucose ratio of obese mice was much higher than that of controls irrespective of the presence of insulin, suggesting that glucose metabolism and insulin sensitivity might be decreased in comparison with lipogenesis from acetate in the adipose tissue from obese mice (Table 2). The metabolic profile was similar to that observed in adipose tissue from yellow KK mice

Table 2. Effects of GTG obesity on tissue weight, liver lipid content, plasma IRI, blood glucose levels and insulin sensitivity, in C57BL mice

\begin{tabular}{|c|c|c|c|}
\hline No. of mice & $\begin{array}{l}\text { Control } \\
5\end{array}$ & $\begin{array}{l}\text { GTG-obese } \\
5\end{array}$ & $P_{\mathrm{d}}$ \\
\hline Body wt., g & $31 \leqq 0.9^{2}$ & $43 \pm 1.0$ & $<0.001$ \\
\hline Epididymal & & & \\
\hline adipose tissue wt., $\mathrm{mg}$ & $546 \pm 44$ & $1391 \pm 58$ & $<0.001$ \\
\hline Liver wt., g & $1.44 \pm 0.06$ & $2.42 \pm 0.16$ & $<0.001$ \\
\hline Liver triglyceride, mg/g & $5.7 \pm 0.7$ & $58.6 \pm 11.5$ & $<0.01$ \\
\hline Liver cholesterol, $\mathrm{mg} / \mathrm{g}$ & $2.0 \pm 0.2$ & $3.3 \pm 0.3$ & $<0.01$ \\
\hline Plasma IRI, $\mu \mathrm{U} / \mathrm{ml}$ & $21.4 \pm 3.4$ & $110 \pm 23$ & $<0.01$ \\
\hline Blood glucose, $\mathrm{mg} / 100 \mathrm{ml}$ & $148 \pm 4$ & $184 \pm 10$ & $<0.02$ \\
\hline Lipogenesis from acetate ${ }^{14} \mathrm{C}^{\mathrm{b}}$ & & & \\
\hline $\begin{array}{l}\text { Liver slice } \\
\text { Epididymal adipose tissue }\end{array}$ & $21.9 \leqq 1.5$ & $41.0 \pm 6.0$ & $<0.02$ \\
\hline $\begin{array}{cl}\text { Insulin concn., } & \mu \mathrm{U} / \mathrm{ml} \\
& 0(\mathrm{~A}) \\
& 10^{3}(\mathrm{~B}) \\
\text { Insulin effect } & (\mathrm{B})-(\mathrm{A}) \\
& (\mathrm{B}) /(\mathrm{A})\end{array}$ & $\begin{array}{l}19.3 \pm 2.6 \\
77.5 \pm 24.0 \\
58.3 \pm 22.2 \\
3.9 \pm 0.8\end{array}$ & $\begin{array}{l}57.5 \pm 6.7 \\
119 \pm 13 \\
61.6 \pm 11.1 \\
2.1 \pm 0.3\end{array}$ & $<0.001$ \\
\hline $\begin{array}{l}\text { Glucose }{ }^{14} \mathrm{C} \text { oxidation }{ }^{\mathrm{c}} \\
\text { Epididymal adipose tissue } \\
\text { Insulin conch }\end{array}$ & & & \\
\hline $\begin{array}{cl}\text { Insulin concn., } & \mu \mathrm{U} / \mathrm{ml} \\
& 0(\mathrm{C}) \\
& 10^{2} \\
& 10^{3}(\mathrm{D}) \\
\text { Insulin effect } & (\mathrm{D})-(\mathrm{C}) \\
& (\mathrm{D}) /(\mathrm{C})\end{array}$ & $\begin{array}{l}165 \pm 17 \\
283 \pm 21 \\
351 \pm 11 \\
186 \pm 10 \\
2.20 \pm 0.17\end{array}$ & $\begin{array}{l}49.3 \pm 2.6 \\
65.8 \pm 4.4 \\
130 \pm 8 \\
80.8 \pm 8.1 \\
f 2.67 \pm 0.21\end{array}$ & $\begin{array}{l}<0.001 \\
<0.001 \\
<0.001 \\
<0.001\end{array}$ \\
\hline $\begin{array}{l}\text { Acetate/glucose ratio } \\
\text { Insulin concn., } \mu \mathrm{U} / \mathrm{ml} \\
0(\mathrm{~A}) /(\mathrm{C}) \\
10^{3}(\mathrm{~B}) /(\mathrm{D})\end{array}$ & $\begin{array}{l}0.12 \pm 0.00 \\
0.22 \pm 0.05\end{array}$ & $\begin{array}{l}1.17 \pm 0.13 \\
0.91 \pm 0.07\end{array}$ & $\begin{array}{l}<0.001 \\
<0.001\end{array}$ \\
\hline
\end{tabular}

GTG-obese C57BL mice were kept for 26 weeks after the intraperitoneal injection of GTG.

\footnotetext{
a $\mathrm{M}$ - S.E.

b mumoles of acetate ${ }^{14} \mathrm{C}$ incorporated into fatty acids $/ 100 \mathrm{mg}$ wet tissue $/ 90 \mathrm{~min}$.

c mumoles of glucose ${ }^{14} \mathrm{C}$ oxidized to $\mathrm{CO}_{2} / 100 \mathrm{mg}$ wet tissue $/ 90 \mathrm{~min}$.

d Probability of difference between control and GTG-obese mice.
}

GTG-obese mice, the liver showed enlargement (as indicated by an increase in tissue weight) accompanied by elevation of its cholesterol and triglyceride contents (Table 2). Lipogenesis from radioactive acetate was also increased in the liver from obese mice Table 2). In the adipose tissue from obese mice, there was a remarkable coexistence of active lipogenesis from acetate and lowered glucose oxidation (Table 2); metabolic activities were calculated on the basis of tissue weight. The ratio of lipogenesis from acetate relative to oxidation of glucose to carbon dioxide in the dynamic phase of obesity [2]. However, the in sulin sensitivity of glucose oxidation by adipose tissue was not so impaired in obese mice when they were compared with controls (Table 2).

$I C R$ mice: There was a marked increase in body weight in GTG-receiving ICR mice when compared with controls, but one obese mouse (No. 6) was distinguished from the other obese mice by a fall in body weight after the 16 th week (Fig. 1). Some comments on this mouse will be made in the discussion. Obese ICR mice developed marked hyperglycemia at 16 th week 
after treatment, differing from $\mathrm{C57 \textrm {BL }}$ mice receiving the same treatment.

Table 3 shows clinical and biochemical data of control and obese mice sacrificed at 20 th week. In obese mice, there were observed similar changes to those found in obese C57BL mice; namely hypertrophy of the liver and adipose tissue, and increased hepatic content of cholesterol and triglyceride (Table 3). They also showed elevated plasma IRI levels compatible with the pathological findings in the pancreas (hypertrophy of islet and degranulation of $B$ cell). metabolism might be preferentially reduced irrespective of the presence of insulin in adipocyte of obese mice with hyperglycemia. These metabolic profiles were previously reported in yellow $\mathrm{KK}$ mice with obesity in the static phase, in which severe hyperglycemia and hyperinsulinemia were established [2].

\section{Diseussion}

There are many papers describing the development of obesity after experimental injury to the hypothala-

Table 3. Effects of GTG obesity on tissue weight, liver lipid content, plasma IRI, blood glucose levels and insulin sensitivity in ICR mice

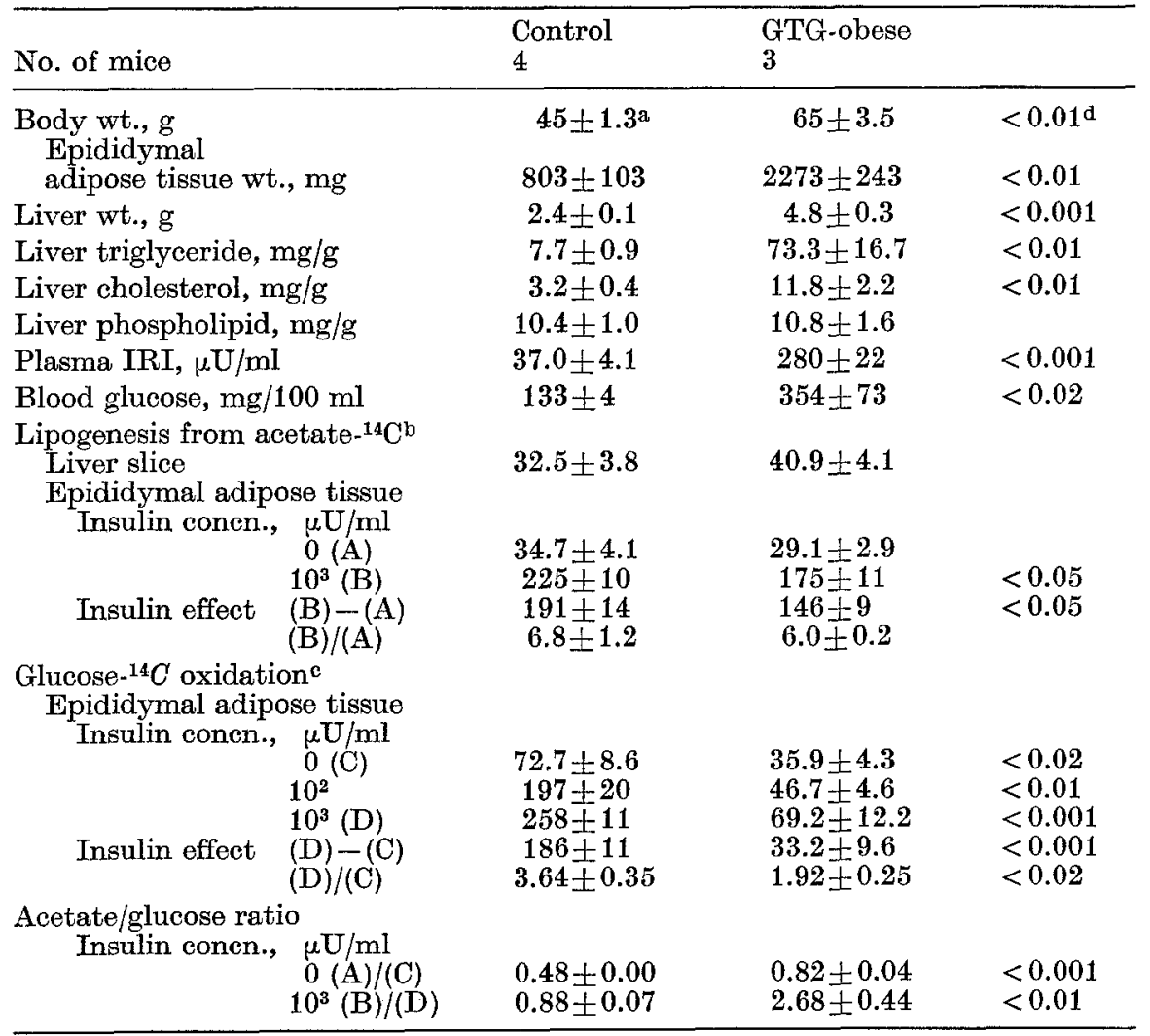
GTG.

GTG-obese mice were kept for 20 weeks after the intraperitoneal injection of

a $\mathbf{M} \leqq \mathbf{S} . \mathbf{E}$

b mumoles of acetate ${ }^{14} \mathrm{C}$ incorporated into fatty acids $/ 100 \mathrm{mg}$ wet tissue $/ 90 \mathrm{~min}$.

e mumoles of glucose- ${ }^{14} \mathrm{C}$ oxidized to $\mathrm{CO}_{2} / 100 \mathrm{mg}$ wet tissue $/ 90 \mathrm{~min}$.

a Numbers in parentheses indicate probability of difference between control and GTG-obese mice.

Lipogenesis from acetate was not elevated in either liver or adipose tissue from obese mice (Table 3). The insulin sensitivity of adipose tissue from the obese mice did not show the same degree of impairment in lipogenesis from acetate as in glucose oxidation (Table 3).

The acetate/glucose ratio was much higher and more sensitive to the addition of insulin in the obese mice than in controls. This suggested that glucose mus [15-20]. It is now well established that a single injection of goldthioglucose into normal mice causes lesions in the ventromedial hypothalamus, often re. sulting in obesity secondary to hyperphagia. In spite of the close association between obesity and diabetes mellitus seen in clinical practice and in genetically diabetic animals, there have been few papers reporting the occurrence of diabetes in laboratory ani- 
mals with experimental hypothalamic lesions. Specifically concerning GTG-obese mice, we have been able to find only one report previously published. Katsuki et al. [19] have demonstrated that five of forty-four mice (ddN strain) receiving GTG exhibited impaired glucose tolerance, insulin resistance and obesity. Four of these showed transient hyperglycemia and glucosuria under some specific condition such as cold stress or following the administration of cortisone.

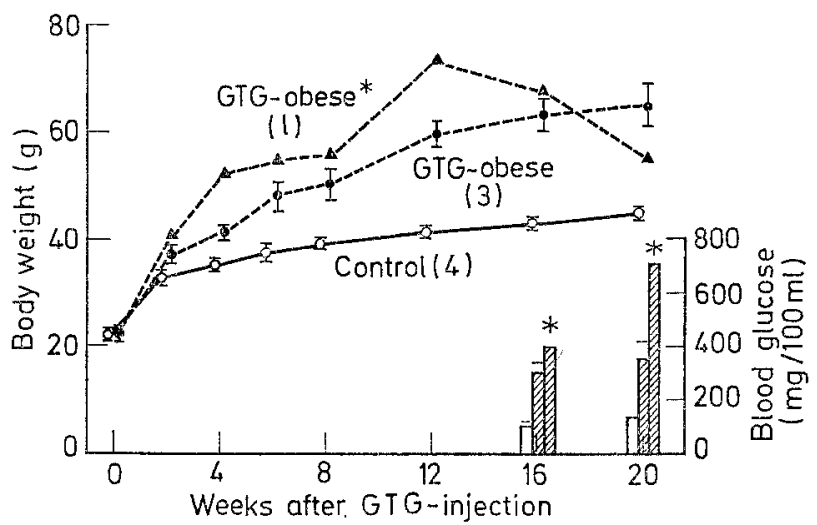

Fig. 1. Weight gains and development of hyperglycemia in GTG-obese ICR mice. Curves = Body weight. Columns $=$ Blood glucose ( $\square$ : Control, um : GTG-obese). I = Standard error of the mean. ()$=$ Number of animals. * = Data of a GTG-obese mouse (No. 6) obesity. The present findings on ICR mice may be the first indication that a diabetic state can be produced in association with GTG obesity in a common laboratory mouse.

Our previous studies showed that ICR mice were metabolically quite normal although they were less tolerant to glucose than C57BL mice, but more tolerant than KK mice. Upon feeding high caloric diets, ICR mice manifested obesity but did not develop any diabetic signs except deterioration in glucose tolerance [1]. GTG obesity, when compared with nutritional obesity, was sufficient to induce hyperglycemia.

In GTG-obese C57BL mice, typical effects of obesity were seen (impairment of glucose tolerance and elevation of the plasma IRI level). Many investigators $[3,22-26]$ have recorded that the C57BL mouse is one of the normal strains so for examined. We also found this strain to be the least diabetic strain in our laboratory [3].

Assuming that in tolerance to glucose indicates the diabetic potential of mice, the order of mice potential for diabetes can be ranked as KK $>$ ICR $>$ C57BL. Table 4 indicates a relationship between diabetic potential and response to obesity. It is clear that obesity accelerates or potentiates the age-dependent development of diabetes, the severity of which depends on the diabetic potential. Table 4 also shows that GTG treatment that caused more marked obesity, induced more

Table 4. Effect of obesity on diabetic state in mice with different diabetic potential

\begin{tabular}{|c|c|c|c|c|}
\hline \multirow[t]{2}{*}{ Mice } & \multirow{2}{*}{$\begin{array}{l}\text { Gonetical diabetic } \\
\text { potential }\end{array}$} & \multicolumn{3}{|c|}{ Diabetic state } \\
\hline & & $\begin{array}{l}\text { Regular } \\
\text { chow }\end{array}$ & $\begin{array}{l}\text { High caloric diet } \\
\text { moderate obesity }\end{array}$ & $\begin{array}{l}\text { GTG } \\
\text { obesity }\end{array}$ \\
\hline $\mathrm{KK} \mathrm{A}^{\mathrm{y}}$ & Diabetic + obese & Overt & Overt & - \\
\hline & Diabetic & Chemical & Overt & Overt \\
\hline ICR & Normala & Normal & Normal & Overt \\
\hline C57BL & Normal & Normal & Normal & Chemical \\
\hline
\end{tabular}

a GTT: less tolerance.

Our previous studies have demonstrated that there is chemical diabetes in non-obese $\mathrm{KK}$ mice [21] and overt diabetes, manifested by hyperglycemia, in obese $\mathrm{KK}$ mice fed a high caloric diets $[1,13]$ or carried $\mathrm{A}^{\mathrm{y}}$ gene (yellow obese) [2]. These observations suggest that obesity either facilitates the development of genetic diabetes or increases penetration of diabetic genes inherited by this strain. This hypothesis was supported by our other experiments, in which the $A^{y}$ gene failed to induce diabetes in hybrid mice $(\mathrm{C} 57 \mathrm{BL} \times \mathrm{KK}$ ) which should carry half of the diabetic genes of KK strain [3].

The present studies showed that hyperglycemia developed not only in KK mice but also in ICR mice with persistent obesity induced by the injection of GTG. Results on KK mice are not surprising but expected, because $\mathrm{KK}$ mice are already known to develop overt diabetes following induction of nutritional profound and intense diabetic changes than simple dietary induction of obesity.

The effect of obesity upon sensitivity to insulin appears to cause diabetic change leading to hyperglycemia, because Salans et al. [27] clearly demonstrated impairment of glucose tolerance and insulin sensitivity of adipocytes in obese human subjects. In the present studies, GTG obesity induced hypertrophy of fat pads and hyperinsulinemia in both ICR and C57BL mice. These observations may indicate dependence of obesity upon lipogenesis activated by insulin. Increased lipogenesis from acetate was confirmed with fat pads and liver from C57BL mice but not with those from obese ICR mice, indicating that obese ICR mice were in the static phase of obesity, during which lipogenesis might return to the normal level at the time of sacrifice. Lowered effectiveness of insulin action was present in obese ICR and C57BL mice, since the in- 
sulinogenic index was increased in both obese mice. It is very interesting that impairment of insulin sensitivity was remarkable only in fat pads from obese ICR mice with hyperglycemia. Therefore, our experimental results support the hypothesis proposed by Bierman and Porte [28] and Cahill et al. [29] that coexistence of "well-insulinized liver" and "diabetic periphery" is important for development of obesity or diabetes accompanying obesity.

When diabetes is assumed to be elevation of blood glucose due to lowered effectiveness of insulin, its onset may depend on the severity of obesity and congenitally determined hormone sensitivity. Previously, we confirmed in KK mice that the genetically impaired sensitivity to insulin was important in the development of diabetes induced by obesity [13]. Similar mechanism can be proposed for the difference in the response to GTG obesity of the two commercial mice, ICR and C57BL.

Observations on a mouse (No. 6) in GTG-obese ICR mice are noteworthy. The mouse showed more advanced signs of diabetes. It reached a maximum weight of $73 \mathrm{~g} 12$ weeks after the administration of GTG and the weight declined to $55 \mathrm{~g}$ at the time of sacrifice. Blood glucose level was extremely high $(712 \mathrm{mg} / 100 \mathrm{ml})$, but plasma insulin level low $(45 \mu \mathrm{U} /$ $\mathrm{ml}$ ) when sacrificed. Pancreatic islets displayed degenerative changes as manifested by reduction in both islet size and number of $B$ cells. These points indicate that hyperglycemia resulted from insulin deficiency in this mouse. Hypoinsulinism could explain other changes observed in the mouse, such as reduction of body weight and adipose tissue weight $(630 \mathrm{mg})$, and lowered lipogenesis by liver and adipose tissue (2.8 and 2.0 mumol of acetate-1 $1{ }^{14} \mathrm{C}$ incorporated into fatty acids/100 $\mathrm{mg}$ wet tissue/90 min, respectively). From these findings, it is postulated that this mouse might have been endowed with an exceptionally low potential of the pancreatic B cell to survive against some exhaustive condition. Usually the pancreas synthesizes and secretes a large amount of insulin to compensate for lowered insulin sensitivity in the periphery secondary to the effect of obesity, demonstrated in the other obese ICR mice cited in Table 3. This pattern resembles the more advanced lesions observed in human diabetes mellitus.

Acknowledgements. The authors thank Dr. Z. Suzuoki and Dr. H. Iwatsuka for their continuing support and invaluable advices. The excellent help of Mr. $\mathbf{K}$. Furuno and Mr. K. Shimakawa with the animal care is gratefully acknowledged.

The authors would like to thank the editors of Diabetologia for editing their manuscript.

\section{References}

1. Matuso, T., Shino, A., Iwatsuka, H., Suzuoki, Z.: Induction of overt diabetes in $\mathrm{KK}$ mice by dietary means. Endocr. jap. 17, $477-488$ (1970).

2. Iwatsuka, H., Shino, A., Suzuoki, Z.: General survey of diabetic features of yellow KK mice. Endocr. jap. 17, 23-35 (1970).

3. Matsuo, T., Shino, A., Iwatsuka, H., Suzuoki, Z.: Studies on diabetogenic action of obesity in mice: Congenital insulin resistance of $\mathrm{KK}$ mice. Endoer. jap. 17, $535-540(1970)$.

4. Kondo, K., Nozawa, K., Tomida, T., Ezaki, K.: Inbred strains resulting from Japanese mice. Bull. exp. Animals 6, 107-112 (1957).

5. Huggett, A.St.G., Nixon, D.A.: Use of glucose oxidase, peroxidase and o-dianisidine in determination of blood and urinary glucose. Lancet $1957 \mathrm{II}, 368-370$.

6. Hales, C.N., Randle, P.J.: Immunoassay of insulin with insulin antibody precipitate. Biochem. J. 88, $127-146$ (1963).

7. Folch, J., Lees, M., Sloane Stanley, G.H.: A simple method for the isolation and purification of total lipides from animal tissues. J. biol. Chem. 226, 497509 (1957).

8. Vogel, W.C., Doizaki, W.M., Zieve, L.: Rapid thinlayer chromatographic separation of phospholipids and neutral lipids of serum. J. Lipid Res. 3, 138-140 (1962).

9. Gerson, T.: The determination of cholesterol and coprostanol in faecal lipids. Biochem. J. 77, 446-448 (1960).

10. Abell, L. L., Levy, B.B., Brodie, B.B., Kendall, F. E.: A simplified method for the estimation of total cholesterol in serum and demonstration of its specificity. J. biol. Chem. 195, 357-366 (1952).

11. Van Handel, E., Zilversmit, D.B.: Micromethod for the direct determination of serum triglycerides. J. Lab. clin. Med. 50, 152-157 (1957).

12. King, E.J.: The colorimetric determination of phos. phorus. Biochem. J. 26, 292-297 (1932).

13. Matsuo, T., Iwatsuka, H., Suzuoki, Z.: Metabolic disturbance of KK mice in overt diabetes. Endocr. jap. 18, 501-506 (1971).

14. Gomori, G.: A new stain for elastic tissue. Amer. J. clin. Path. 20,665 (1950).

15. Marshall, N. B., Barrnett, R.N., Mayer, J. : Hypothalamic lesions in goldthioglucose injected mice. Proc. Soc. exp. Biol. 90, 240-244 (1955).

16. Liebelt, R.A., Perry, J.H.: Hypothalamic lesions associated with goldthioglucose-injected obesity. Proc. Soc. exp. Biol. 95, $774-777$ (1957).

17. Liebelt, R.A., Perry, J.H., Sekiba, K., Liebelt, A.G.: Genetic susceptibility to goldthioglucose-induced obesity in mice. Proc. Soc. exp. Biol. 104, 689-692 (1960).

18. Hales, C.N., Kennedy, G.C.: Plasma glucose, nonesterified fatty acid and insulin concentrations in hypothalamic-hyperphagic rats. Biochem. J. 90, $620-625$ (1964).

19. Katsuki, S., Hirata, Y., Horino, M., Ito, M., Ishimoto, M., Makino, N., Hososako, A.: Obesity and hyperglycemia induced in mice by goldthioglucose. Diabetes 11, 209-215 (1962).

20. Malaisse, W.J., Malaisse-Lagae, F., Coleman, D.L.: Insulin secretion in experimental obesity. Metabolism 17, 802-807 (1968).

21. Iwatsuka, H., Matsuo, T., Shino, A., Suzuoki, Z.: Metabolic disturbance of $\mathrm{KK}$ mice in chemical diabetes. J. Takeda Res. Lab. 29, 685-692 (1970).

22. Fenton, P.F., Carr, C. J.: The nutrition of the mouse. XI. Response of four strains to diets differing in fat content. J. Nutr. 45, 225-233 (1951).

23. Fenton, P.F., Carr, C.J.: Dowling, M.T.: Studies on 
obesity. I. Nutritional obesity in mice. J. Nutr. 49, $319-331$ (1953).

24. Adams, J.T., Titos, P.A., Weir, J.A.: Metabolism of glucose by C57BL/6 mice. Amer. J. Physiol. 213, $231-234$ (1967).

25. Nakamura, M., Yamada, K. : Studies on diabetic (KK) strain of the mouse. Diabetologia 3, 212-221 (1967).

26. Lavine, R.L., Chick, W.L., Like, A.A.: Glucose tolerance and insulin secretion in neonatal and adult mice. Diabetes 20, 134-137 (1971).

27. Salans, L.B., Knittle, J.L., Hirsch, J.: The role of adipose cell size and adipose tissue insulin sensitivity in the carbohydrate intolerance of human obesity. J. clin. Invest. 47, 153-165 (1968).
28. Bierman, E.L., Porte, D., Jr.: Carbohydrate intolerance and lipemia. Ann. intern. Med. 68, 926-933 (1968).

29. Cahill, G.F., Jr., Jones, E.E., Lauris, V., Steinke, J., Soeldner, J.S.: Studies on experimental diabetes in the Wellesley hybrid mouse. II. Serum insulin levels and response of peripneral tissue. Diabetologia $\mathbf{3}$, $171-174$ (1967).

\section{T. Matsuo}

Biological Research Laboratories Central Research Division

Takeda Chemical Industries, Ltd. Juso, Higashiyodogawa-ku, Osaka, Japan 